\title{
Effect of Stress on Haemato-biochemical Parameters Alteration during Slaughter in Pigs
}

\author{
Sanju Mandal ${ }^{1 *}$, Subhradal Nath $^{2}$ and Sulochana Sen $^{3}$ \\ ${ }^{I}$ Department of Veterinary Physiology \& Biochemistry, ${ }^{2}$ Department of Veterinary \\ Parasitology, ${ }^{3}$ Department of Animal Genetics, C.O.V.Sc \& A.H. \\ Jabalpur (M.P.) 482001, India \\ *Corresponding author
}

\section{A B S T R A C T}

\section{Keywords}

Slaughter, Blood,

Haemato-

biochemical, Pig

\section{Article Info}

Accepted:

24 July 2020

Available Online:

10 August 2020

\begin{abstract}
The objective of the study was to assess the changes acquired in haematological and biochemical parameters attributed to stress during slaughter in pigs. The study was conducted in twenty pigs. The blood sample was collected under aseptic condition from twenty pigs before slaughter at instructional pig farm and during slaughter from abattoir. On statistical analyses (mean was compared with t-test), it was observed that the haemoglobin, total erythrocyte count decreased and packed cell volume increased significantly $(\mathrm{P}<0.05)$. Biochemical parameters; albumin, Aspartate Transaminase and creatinine kinase significantly increased $(p<0.05)$, while globulin, Blood Urea Nitrogen and creatinine decreased significantly $(p<0.05)$. Significant increase $(p<0.01)$ in of concentration cholesterol and total protein were recorded. Concentration of sodium and chloride decreased significantly $(\mathrm{p}<0.01)$ and potassium was increased significantly $(\mathrm{p}<0.01)$ due to slaughter. The study concluded that animals after slaughter can show metabolic alteration that leads to hyperglycaemia, increased lactate and descent of $\mathrm{pH}$.
\end{abstract}

\section{Introduction}

Blood circulating in the body, carrying substances to and fro, is the first by-product obtained after slaughtering an animal. The meat quality has a direct association with pre slaughter handling and even animals treated under top animal-welfare conditions may have their meat quality compromised if handling is not appropriately performed. Handling of animal's pre and post slaughter affecting quality of meat can be assessed by studying the haemato-biochemical parameters
(Louise et al., 2014). It is also the primary source of animal protein. Some cultures in India and the world, consume blood as food, often in combination with meat (Davidson, 2006).

Haematological parameters are good indicators of the physiological status of animals (Adenkola and Durotoye, 2004). It is also an excellent medium for the measurement of potential biomakers, because its collection is relatively noninvasive and it encompasses an enormous range of 
physiological process in the body at any given time (Anderson and Anderson, 2002; Ginsburg and Haga, 2006).

Information from biochemical profile is used to determine the pig health condition. Transport is stressful for pig, decrease animal welfare and meat quality (Mota-Rojas et al., 2006; Becerril-Herrera et al., 2007) evaluate several blood variables and their relations to stress. It is reported that animal transportation and lairage causes acute stress and it affects the hematological and biochemical parameters ultimately has a negative effect on meat quality (Averos et al., 2007).

Thus, the present work was aimed to assess the alteration in haemato-biochemical parameters based on handling of pigs during slaughter. There are large number of previous reports were present on the haematobiochemical profile alteration in blood for meat animals but in pigs, very few studies have done so far in respect to pre slaughter transport, lairage stress on blood haematobiochemical parameters. Hence the present study was to evaluate haemato-biochemical changes of pig blood before and after slaughtering.

\section{Materials and Methods}

The study was carried out by aseptic collection of blood sample from twenty pigs, at pre-slaughter stage at instructional pig farm and from the same pigs during slaughter from local abattoir in heparinized and nonheparinized vials.

Blood was collected by jugular vein puncture and at exsanguinations during slaughter (Salajpal et al., 2005). The non-heparinized blood samples were centrifuged at $2500 \mathrm{rpm}$ for $10 \mathrm{~min}$. The obtained serum was refrigerated at $2^{0} \mathrm{C}$ for further biochemical analysis.

\section{Haematological analysis}

Blood samples were analyzed for packed cell volume (PCV) using microhaematocrit method, total erythrocyte count (TEC) using haemocytometer method, haemoglobin $(\mathrm{Hb})$ concentration, blood indices (MCV, MCHC, $\mathrm{MCH})$ as described by Schalm et al., (1975). The $\mathrm{pH}$ was measured in blood before and after slaughter, using a Testo $205 \mathrm{pH}$-meter.

\section{Biochemical Analysis}

Total protein was estimated by the biuret reaction (Peters et al., 1982), serum albumin by bromocresol green method, globulin by calculating the difference between total protein and albumin, glucose was estimated by Folin-Wu method, Creatinine was determined by the Jaffe reaction method (Seaton and Ali, 1984) and BUN (Blood urea nitrogen) by diacetyl mono-oxime methods described by Harold, 1988. Serum lactate estimated through the Chemiluminescence and Kinetic enzymatic techniques; serum calcium and cholesterol were determined using the procedure described by Kaneko et al., (2008). Sodium and potassium were estimated by Flame photometery (Hawks et al., 1954).

Serum enzymes Phosphorus and chloride $\left(\mathrm{Cl}^{-}\right)$ Aspartate Transaminase (AST) and creatinine kinase (CK) were estimated by commercial kit, manufactured by ERBA Company Limited, with Semi-autoanalyzer. The standardized protocol provided with the ERBA kit was followed for estimation.

\section{Statistical analysis}

Statistical analysis was done with statistical package for social sciences (SPSS) statistical software version 11.0 (Grade et al., 2010). Comparison of different parameters in before and after slaughtered blood was done by t-test. 


\section{Results and Discussion}

Haematol-biochemical values before and after slaughter are shown in Table No. 1. Preslaughtered calculated values of Haemoglobin concentration, PCV, TEC, MCV, MCH, MCHC were $10.31 \pm 0.32,30.86 \pm 1.54,6.54 \pm$ $0.81,47.18 \pm 0.21,15.76 \pm 0.35,33.40 \pm 0.15$ respectively; whereas in Post slaughter 9.64 \pm $0.24,31.27 \pm 0.45,5.40 \pm 0.64,57.90 \pm 0.01$, $17.85 \pm 0.15,30.82 \pm 0.30$ respectively. In the present study Hemoglobin, total erythrocyte count and MCHC were decreased significantly $(\mathrm{p}<0.05)$. It was observed the values of packed cell volume, $\mathrm{MCH}, \mathrm{MCV}$ increased significantly $(p<0.05)$.

Assessment of biochemical parameters in Table No. 1 revealed that total protein and albumin concentration increased in slaughtered blood from $2.41 \pm 0.35$ to $3.61 \pm 0.14$ and $7.45 \pm 0.42$ to $8.91 \pm 0.30$ respectively while globulin value before and after slaughter $5.34 \pm 0.07$ and $5.03 \pm 0.16$; decreased significantly $(\mathrm{p}<0.05)$. Aspartate Transaminase and Creatinine Kinase (CK) value in Pre-slaughter blood was $27.50 \pm 0.89$ and $462.59 \pm 14.82$; for post slaughter $32.54 \pm 0.64$ and $594.65 \pm 10.38$ value increased significantly $\quad(\mathrm{p}<0.05)$. There was significantly $(\mathrm{p}<0.01)$ increased value of glucose from $85.25 \pm 1.05$ to $113.50 \pm 1.89$ and cholesterol $52.08 \pm 1.58$ to $102.12 \pm 4.32$ were observed. Blood lactate $(5.10 \pm 0.35$ to $21.67 \pm 0.14)$ was also increased significantly $(\mathrm{p}<0.05)$ after slaughter. Pre-slaughter and post slaughter values of BUN were $22.46 \pm$ 0.36 and $16.16 \pm 0.86$ respectively. Preslaughter value $(1.42 \pm 0.36)$ of creatinine was significantly higher $(\mathrm{p}<0.05)$ than postslaughter values $(1.05 \pm 0.41)$.

Blood calcium $(\mathrm{Ca})$ and phosphorous $(\mathrm{P})$ concentrations decreased significantly $(\mathrm{p}<0.05)$ from $8.94 \pm 0.27$ to $4.96 \pm 0.35$ and $2.54 \pm 0.17$ to1.94 \pm 0.19 after slaughter.
Before and after slaughter sodium concentration was $143.6 \pm 1.66$ and $84.6 \pm 11.66$ respectively; chloride concentration was $98.34 \pm 8.74$ and $67.85 \pm 5.59$; potassium concentration was $2.42 \pm 0.12$ and $4.56 \pm 0.06$. Blood Sodium and Chloride concentrations decreased significantly $(\mathrm{p}<0.01)$ whereas blood Potassium concentration was increased significantly $(\mathrm{p}<0.01)$ after slaughter.

Total protein and albumin concentration increased significantly due to slaughter, while globulin decreased significantly. This observation is supported by the report of Rojas et al., (2009) for pig. The significant alternation in albumin and globulin is attributed to pre-slaughter and stunning stress. Hemoglobin and TEC level decreased in after slaughtered due to blood loss due to slaughter, albumin concentration might have increased, due to increase in packed cell volume, owing to dehydration or splenic contraction, induced by sympathetic nerve activity or circulating catecholamines (Tadich et al., 2005). The explanation behind the decrease of globulin might be the fact that stunning stress might have caused reduction of immunoglobins by immuno-supression (Lee et al., 2000). Hence, the increase of albumin compensating globulin decrease prevented the alternation of total protein.

Aspartate Transaminase increased in post slaughtered blood. Werner et al., (2010) reported significant increased Aspartate Transaminase activity within $40 \mathrm{~min}$ postmortem in Duroc-Pietrain crossbreed pig. After $12 \mathrm{~h}$, the activity of the enzyme decreased to the amount of the pre-slaughter samples. They concluded that Aspartate Transaminase influence the muscle-to-meat transition process after slaughter of the animals without an impact on the muscle quality. 
Table.1 Haemato-biochemical parameters of pre and post slaughter of pig blood

\begin{tabular}{|c|c|c|c|}
\hline S. No. & Parameters & Pre-Slaughter & Post Slaughter \\
\hline 1. & Albumin $(\mathrm{g} / \mathrm{dl})$ & $2.41^{\mathrm{a}} \pm 0.35$ & $3.61^{b} \pm 0.14$ \\
\hline 2. & Blood urea nitrogen $(\mathrm{mg} / \mathrm{dl})$ & $22.46^{\mathrm{a}} \pm 0.36$ & $16.16^{\mathrm{b}} \pm 0.86$ \\
\hline 3. & Calcium (mg/dl) & $8.94^{\mathrm{a}} \pm 0.27$ & $4.96^{b} \pm 0.35$ \\
\hline 4. & Cholesterol (mg/dl) & $52.08^{c} \pm 1.58$ & $102.12^{\mathrm{d}} \pm 4.32$ \\
\hline 5. & Chloride $(\mathrm{mmol} / \mathrm{L})$ & $98.34^{\mathrm{c}} \pm 8.74$ & $67.85^{\mathrm{d}} \pm 5.59$ \\
\hline 6. & Creatinine (mg/dl) & $1.42^{\mathrm{a}} \pm 0.36$ & $1.05^{b} \pm 0.41$ \\
\hline 7. & Globulin (g/dl) & $5.34^{\mathrm{a}} \pm 0.07$ & $5.03^{b} \pm 0.16$ \\
\hline 8. & Glucose $(\mathrm{mg} / \mathrm{dl})$ & $85.25^{\mathrm{c}} \pm 1.05$ & $113.50^{\mathrm{d}} \pm 1.89$ \\
\hline 9. & Lactate $(\mathrm{mmol} / \mathrm{l})$ & $5.10^{\mathrm{a}} \pm 0.35$ & $21.67^{\mathrm{b}} \pm 0.14$ \\
\hline 10. & Potassium (mmol/L) & $2.42^{\mathrm{c}} \pm 0.12$ & $4.56^{\mathrm{d}} \pm 0.06$ \\
\hline 11. & Phosphorus (mmol/L) & $2.54^{\mathrm{a}} \pm 0.17$ & $1.94^{b} \pm 0.19$ \\
\hline 12. & Sodium $(\mathrm{mmol} / \mathrm{L})$ & $143.6^{c} \pm 1.66$ & $84.6^{\mathrm{d}} \pm 11.66$ \\
\hline 13. & Total bilirubin (mg/dl) & $0.14^{\mathrm{a}} \pm 0.07$ & $0.28^{b} \pm 0.09$ \\
\hline 14. & Total protein $(\mathrm{g} / \mathrm{dl})$ & $7.45^{c} \pm 0.42$ & $8.91^{\mathrm{d}} \pm 0.30$ \\
\hline 15. & AST (U/L) & $27.50^{\mathrm{a}} \pm 0.89$ & $32.54^{b} \pm 0.64$ \\
\hline 16. & Creatine kinase (U/L) & $462.59^{\mathrm{a}} \pm 14.82$ & $594.65^{\mathrm{b}} \pm 10.38$ \\
\hline 17. & Blood $\mathrm{pH}$ & $7.34^{\mathrm{a}} \pm 0.01$ & $7.03^{b} \pm 0.01$ \\
\hline 18. & Haemoglobin & $10.31^{\mathrm{a}} \pm 0.32$ & $9.64^{b} \pm 0.24$ \\
\hline 19. & Packed Cell Volume (PCV) & $30.86^{\mathrm{a}} \pm 1.54$ & $31.27^{b} \pm 0.45$ \\
\hline 20. & $\operatorname{TEC}\left(\times 10^{6} / \mathrm{mm}^{3}\right)$ & $6.54^{\mathrm{a}} \pm 0.81$ & $5.40^{b} \pm 0.64$ \\
\hline 21. & MCV (fl) & $47.18^{\mathrm{a}} \pm 0.21$ & $57.90^{b} \pm 0.01$ \\
\hline 22. & $\mathrm{MCH}(\mathrm{pg})$ & $15.76^{\mathrm{a}} \pm 0.35$ & $17.85^{b} \pm 0.15$ \\
\hline 23. & $\operatorname{MCHC}(\mathrm{g} / \mathrm{dL})$ & $33.40^{\mathrm{a}} \pm 0.15$ & $30.82^{b} \pm 0.30$ \\
\hline
\end{tabular}

Note: Mean with superscripts $(a, b)$ in a row differ significantly $(\mathrm{p}<0.05)$. Mean with superscripts $(c, d)$ in a row differ significantly $(\mathrm{p}<0.01)$.

Creatinine Kinase (CK) increased in blood concentration which also supported the result of Smiecinska et al., (2011). Serum CK activity was higher in blood samples collected during carcass bleeding than in samples collected before, pointing to a strong stress response of animals to pre-slaughter treatment. They suggested that rest before slaughter alleviated stress, induced by preslaughter handling operations.

There was significantly increased value of glucose and cholesterol. Guha et al., (2012) reported that slaughter caused hyperglycemia in buffaloes. Averos et al., (2007) also reported significant increase of blood glucose in post slaughter blood in pigs. Cortisol produces more glucose by acting on the liver, increasing the synthesis of some enzymes which promote gluconeogenesis, in order to provide the body with instant energy (Werner and Gallo, 2008). The high sugar levels, however, often are not used up by the body and eventually are converted to fatty acids and cholesterol (Coleman et al., 1998). Lynch et al., (1964) attributed the increase of blood glucose level to rapid glycogenolysis in the liver after death.

Increased level of cholesterol and Lactate observed in post slaughtered pigs. These results were similar to those found Warriss et 
al., (1994), in which the pigs subjected to high stress had higher levels of cortisol and lactate. In the pre-slaughter handling, animals get severely stressed, a condition that leads to increased levels of cortisol and lactate in their bloodstream, and may have as consequence a decrease in the meat quality (D'Eath et al., 2010). Present study decreased value of BUN and creatinine, same was observed in the study of Marai et al., (2006). They attributed it to stress, which might be due to heat, psychotic or stunning. It was observed that blood calcium $(\mathrm{Ca})$ and phosphorous $(\mathrm{P})$ concentrations decreased after slaughter. Significant hypocalcemia was also reported by Mandal et al., (2013) in slaughtered goat, this might be due utilization of $\mathrm{Ca}$ ions by calpain proteolytic system Calcium is also utilized to maintain heart-beat and blood clotting mechanism (Kaneko et al., 2008). Phosphorous required to carry out vital body functions. The significant decrease of Phosphorus is attributed to their utilization during body exposure to stress bearing factors during slaughter (Wojcik et al., 2009).

Slaughter also affected the electrolyte profile, which plays an important role in homeostasis, acid-base balance, osmotic pressure, neural transmission, etc. Earlier, Wojcik et al., (2009) reported similar observation for broiler chicken. Schaefer et al., (1997) reported alternation in electrolyte profile in post slaughter blood of pigs, which they attributed to transport stress. They proved it, by supplementing electrolytes in drinking water of pigs, during and after transport. Death will cause the potassium $(\mathrm{K})$ to be released from tissue or from liver into the blood. During stress, epinephrine might play a role in the release of $\mathrm{K}$ from brain cell in the blood. To maintain the electrical neutrality, sodium $(\mathrm{Na})$ will move from the blood into the cells to carry out vital function at death. Chloride $\left(\mathrm{Cl}^{-}\right.$ ) moves with the electrical gradient along with $\mathrm{Na}$ (Lynch et al., 1964).

\section{Acknowledgement}

The authors highly acknowledge dean college of Veterinary Science and A.H., Rewa (M.P.), for providing funds and facility for this research.

\section{References}

Adenkola, A.Y., Durotoye, L.A. 2004. Haematological study during prepartum and postpartum periods in brown savanna does in Zaria, Nigeria. Proceedings 38th Annual Conference Agricultural Society Nigeria. 538-540.

Anderson, N.L., Anderson, N.G. 2002. The human plasma proteome: History, character, and diagnostic prospects. Mol. Cell. Proteomics. 1:845-867

Averos, X., Herranz, A., Sanchez, R., Comella, J.X. and Gosalvez, L.F. 2007. Serum stress parameters in pigs transported to slaughter under commercial conditions in different seasons. Vet. Med. 52:333-342.

Becerril-Herrera, M., Mota-Rojas, I., Guerrero-Legarreta, M., GonzalezLozano, P., Sanchez-Aparicio, C., Lemus-Flores, S., Flores-Peinado, R., and Alonso-Spilsbury, M., 2007. Effect of additional space during transport on pre-slaughter traits of pigs. $J$. Biol.Sci., 7(7):1112-1120.

Coleman, C.A., Friedman, A.G. and Burright, R.G. 1998. The relationship of daily stress and health related behaviors to adolescents' cholesterol levels. Adolescence 33:447-460.

Davidson, A. (2006). The Oxford Companion to Food. Second Ed. Oxford University Press, UK pp. 45-54.

D'Eath, R. B., Turner, S. P., Kurt, E., Evans, G., Thölking, L., Looft, H., Wimmers, K., Murani, E., Klont, R., Foury, A., Ison, S. H., Lawrence, A. B. and Mormède, P. 2010. Pigs' aggressive 
temperament affects pre-slaughter mixing aggression, stress and meat quality. Animal 4:604-616.

Grade, N.E., Singh, G., Pankaj, R. and Mahapatra R.K. 2010. Effect of ascorbic acid supplementation on plasma profile in buffaloes during heat stress. Ind. J. Vet. Res. 19:56-62.

Ginsburg, G.S., Haga, S.B. 2006. Translating genomics biomakers into clinically useful diagnostics. Expert. Rev..Mol. Diagn. 6: 179-191

Guha, A., Guha, R., Mandal, S. and Gera, S. 2012. Study on the alteration of bubaline blood biochemical composition owing to slaughter, African Journal of Biotechnology., 11(57):12134-12137.

Harold, S. 1988: Practical Clinical Biochemistry. C.B.S. Publishers, New Delhi, 132-140.

Hawks, P.B., Oser, B.L. and Summerson, W.H. 1954. Practical Physiological Chemistry. Thirteen Ed. McGraw-Hill, London.

Kaneko, J.J., Harvey, J.W. and Bruss, M.L. 2008. Clinical Biochemistry of Domestic Animals. Six Ed., Academic Press, London pp. 235-255.

Lee, J.R., Kim, D.H., Kim, K.S., Moon, S.S., Joo, S.T. and Park, G.B. 2000. The effect of transport and lairage on the blood profile of slaughtered pig. $J$. Anim. Sci. Technol. (Kor.) 42:677-684.

Louise, M., Peres, L., Maria, A., Caio, A., Andreo1, N., AvenaTarsitano, M., Leticia, E., Stivaletti, T. 2014. Effect of low or high stress in pre-slaughter handling on pig carcass and meat quality Revista Brasileira de Zootecnia. R. Bras. Zootec. 43(7):363-368.

Lynch, G.P., Fulmine, F.J. and Hiner, R.L. 1964. Some indications of physiological stress in lambs subjected to various pre-slaughter treatments. $J$. Anim. Sci. 23:661-664.
Mandal, S. and Nath, S. 2013. Biochemical alteration in caprine blood before and after slaughter, Environment \& Ecology., 31(2C):1128-1132.

Marai, I.F.M., Ayyat, M.S. and El-Monem, U.M.A. 2006. Growth performance, blood components, slaughter trait of New Zealand white rabbits affected by dietary supplementation with calcium, sodium or potassium in sub-tropical Egypt. Trop. Sub-trop. Agroecosyst. 6: 49-155.

Mota-Rojas, D., Becerril-Herrera, M., Lemus, C., Sanchez, P., Gonzalez, M., Olmos, A., Ramirez, R., and Alonso-Spilsbury, M., 2006. Effect of mid-summer transport duration on pre and postslaughter performance and pork quality in Mexico. Meat Sci.73:404-412.

Peters, T., Biamonte, G. T. and Doumas, B. T. 1982. Proein (total protein) in serum, urine and cerebrospinal fluid. In: Selected Methods in Clinical Chemistry, Vol. 9. (Faulkner, W. R., S. Meites, Eds.). American Assoc. Clinical Chemistry, Washington D. C., USA.

Rojas, D.M., Herrera, M.B., Ortega, M.E.T., Spilsbury, M.A., Peinado, S.C.F. and Legarreta, I.G. 2009. Effects of preslaughter transport, lairage and sex on pig chemical serologic profiles. $J$. Anim. Vet. Adv. 8:246-250.

Salajpal, K., Dikic, M., Karolyi, K., Sinjeri, Z., Liker, B., Kostelic, A. and Juric, I. 2005. Blood serum metabolites and meat quality in crossbred pigs experiencing different lairage time. Ita. J. Anim. Sci. 4:119-121.

Schaefer, A.L., Jones, S.D.M. and Stanley, R.W. 1997. The use of electrolyte solutions for reducing transport stress. J. Anim. Sci. 75:258-265.

Schalm, O. W., Jain, N. C., Caroll, E. J. 1975. Textbook of Veterinary Haematology Published by Lea and Febiger 
Philadelphia. 2:129 - 250 .

Seaton, A. and Ali, A. 1984. Serum creatinine estimation. Med. Lab. Sci. 41: 327-336.

Smiecińska, K., Denaburski, J. and Sobotka, W. 2011. Slaughter value, meat quality, creatine kinase activity and cortisol levels in the blood serum of growingfinishing pigs slaughtered immediately after transport and after a rest period. Pol. J. Vet. Sci. 14:47-54.

Tadich, N., Gallob, C., Bustamantea, H., Schwertera, M. and Schaikc, G.V. 2005. Effects of transport and lairage time on some blood constituents of Friesian-cross steers in Chile. Livest. Prod. Sci. 93: 223-233.

Warriss, P. D. Brown, S. N., Adams, S. J. and Corlett, I. K. 1994. Relationships between subjective and objective assessments of stress at slaughter and meat quality in pigs. Meat Science 38:329-340.
Werner, M. and Gallo, C. 2008. Effect of transport, lairage and stunning on the concentrations of some blood constituents of horses destined for slaughter. Livest. Sci. 115:94-98.

Werner, C., Natter, R. and Wicke, M. 2010. Changes of the activities of glycolytic and oxidative enzymes before and after slaughter in the longissimus muscle of Pietrain and Duroc pigs and a DurocPietrain crossbreed. J. Anim. Sci. 88:4016-4025.

Wojcik, A., Mituniewicz, T., IwanczukCzernik, K., Sowinska, J., Witkowska, D. and Chorazy, L. 2009. Contents of macro- and microelements in blood serum and breast muscle of broiler chickens subjected to different variants of pre-slaughter handling. Czech. J. Anim. Sci. 54:175-181.

\section{How to cite this article:}

Sanju Mandal, Subhradal Nath and Sulochana Sen. 2020. Effect of Stress on Haematobiochemical Parameters Alteration during Slaughter in Pigs. Int.J.Curr.Microbiol.App.Sci. 9(08): 3014-3020. doi: https://doi.org/10.20546/ijcmas.2020.908.340 